\title{
Boyle's law. A lecture experiment
}

\section{J.L. Andreae}

To cite this article: J.L. Andreae (1884) Boyle's law. A lecture experiment, Philosophical Magazine Series 5, 18:110, 80-80, DOI: 10.1080/14786448408627569

To link to this article: http://dx.doi.org/10.1080/14786448408627569

册 Published online: 29 Apr 2009.

Submit your article to this journal

Џ Article views: 2

Q View related articles $₫$ 
ON THE MANNER IN WHICH THE CURRENT OF AN INDUCTION FRICTIONAL MACHINE IS AFFECTED BY THE MOISTURE. BY R. KRÜGER.

The results of this investigation may be summarized as follows:-

1. The connexion between the strength of the current of an induction machine and the moisture may be expressed by the formula

$$
i=i_{0}-\alpha \rho^{2}=i_{0}\left(1-\frac{\rho^{2}}{\rho_{0}^{2}}\right) ;
$$

in which $i$ is that strength of current which would be obtained if there were no moisture at all, and $\rho_{0}$ is that degree of moisture at which the machine would not work. This formula holds for any degree of relative moisture with perfect accuracy.

2. The constant $\rho_{0}=\sqrt{\frac{i_{0}}{\alpha}}$ is greater as the velocity of rotation increases ; that is, when the machine is rotated with greater velocity, its current first disappears at higher degrees of moisture than when the rotation is less rapid.

3. The quantity of electricity given by one turn of the plate when there is no moisture is essentially independent of the velocity of rotation; and the quantity of electricity which in this case passes through the section of the conducting wire amounts to $458,33.80^{5}$ electrostatic units.

Some observations intended to ascertain how far the current depends on the distance of the points from the movable plate, and, on the other hand, on the distance of the plates from each other, showed a decrease of strength with greater distance; but it was not possible to establish a definite law.-Wiedemann's Annalen, No. $6,1884$.

\section{BOYLE'S LAW. A LECTURE EIXPERIMENT.}

BY J. L. ANDREAE.

In a glass tube, about a metre long and from $1 \frac{1}{2}$ to 2 millim, internal diameter, closed at one end and open below, is introduced a thread of mercury about 250 millim. in length. This encloses a certain volume of air, which is about 40 cub. centim.

The tube is supported on a stand, which has a scale on white paper divided in centimetres, and caul be placed on the table with either end vertical. If $H$ is the height of the barometer in millimetres, the pressure of the enclosed air is $\mathrm{P}=\mathrm{H}-250$. If the tube is inverted, the pressure is $\mathrm{P}^{\prime}=\mathrm{H}+250$. If $\mathrm{H}=750, \mathrm{P}=500$ and $\mathrm{P}^{\prime}=1000$, so that the volume is reduced from 40 to 20 .

This simple apparatus has the advantage that it is always ready for use, and hence does not need to have the mercury poured in as in the usual form.-Wiedemann's Annaten, No. 6, 1884. 